\title{
PENGARUH EFISIENSI BIAYA PEMELIHARAAN MESIN TERHADAP PRODUKTIVITAS PRODUKSI
}

\author{
Ima Ammelia
}

\begin{abstract}
Abstrak
Penelitian ini bertujuan untuk mengetahui gambaran efisiensi biaya pemeliharaan mesin, mengetahui gambaran produktivitas produksi, serta untuk mengetahui pengaruh efisiensi biaya pemeliharaan mesin terhadap produktivitas produksi. Metode penelitian yang digunakan adalah metode deskriptif-verifikatif. Data yang digunakan dalam penelitian ini adalah data sekunder berupa laporan keuangan. Analisis data dilakukan dengan menggunakan uji linieritas dan regresi linier sederhana dengan menggunakan program SPSS versi 20. Hasil penelitian diperoleh persamaan regresi $\hat{Y}=1,615-0,029 X$ menunjukan arah koefisien negatif. Kesimpulan penelitian menunjukan bahwa efisiensi biaya pemeliharaan mesin tinggi, produktivitas produksi rendah, perhitungan statistik menunjukan koefisien arah regresi negatif. Hal ini menunjukan setiap adanya kenaikan efisiensi biaya pemeliharaan mesin akan menurunkan produktivitas produksi, dan sebaliknya. Dengan demikian hipotesis yang diajukan adalah efisiensi biaya pemeliharaan mesin berpengaruh negatif terhadap produktivitas produksi diterima.
\end{abstract}

Kata Kunci : Efisiensi Biaya Pemeliharaan Mesin, Produktivitas Produksi

\section{Pendahuluan}

2010 Sesuai dengan Inpres No 1 Tahun Prioritas Pembangunan Nasional Tahun 2010, Kementrian Perindustrian mengimplementasikan Program Revitalisasi Industri Gula Nasional dengan visi mewujudkan industri gula nasional yang mandiri, berdaya saing dan mampu memenuhi kebutuhan dalam negeri dan ekspor. Adapun misi program ini adalah: memperkuat struktur industri gula, meningkatkan produktivitas dan efisiensi, mendorong investasi pabrik gula ke luar Pulau Jawa, terpenuhinya kebutuhan gula konsumsi dan industri oleh industri gula dalam negeri dan mendorong industri permesinan dalam negeri untuk mendukung revitalisasi industri gula. Pelaksanaan program ini berkoordinasi dengan instansiinstansi lainnya.
Program revitalisasi industri gula 20102014 ini diimplementasikan dengan sasaran pokok untuk mencapai swasembada gula nasional pada tahun 2014 dengan produksi gula konsumsi 2,96 juta ton dan gula untuk industri sebesar 2,74 juta ton. Dengan demikian, total produksi gula pada tahun 2016 diharapkan mencapai 5,7 juta ton. Sedangkan tingkat produksi industri gula nasional saat ini baru mencapai 2,7 juta ton, sehingga masih defisit 3 juta ton. Untuk menutupi defisit kebutuhan gula nasional serta mencapai swasembada gula, diperlukan peningkatan produktivitas pabrik gula yang telah ada dan penambahan sedikitnya 20 pabrik gula baru. Selain itu, industri gula dihadapkan dengan ketentuan Asean Free Trade Area (AFTA), tarif bea masuk untuk Gula Kristal Putih (GKP) harus turun menjadi $10 \%$ dan gula mentah (raw sugar) harus turun menjadi 5\%. Gula produksi luar negeri akan membanjiri pasar Indonesia. Perbedaan harga gula produksi 
dalam negeri dengan luar negeri akan membuat gula Indonesia tidak mendapat tempat di pasar meskipun produksi dalam negeri dapat mencukupi konsumsi nasional. Maka dari itu masih diperlukan usaha-usaha untuk membangun industri gula Indonesia agar memiliki daya saing.

PT Raya Sugarindo Inti Tasikmalaya sebagai salah satu perusahaan swasta yang bergerak dibidang industri gula ikut berperan serta dalam pertumbuhan gula nasional. PT Raya Sugarindo Inti Tasikmalaya yang berproduksi di JI Raya Singaparna Km 9,8 Tasikmalaya ini memproduksi jenis gula cair yaitu glucose, fructose, caramel, dextrose monohydrate dan maltodextrin. Gula cair tersebut diditribusikan ke beberapa industri makanan dan minuman diantaranya PT Mayora Indah, PT Perfetti Vanmelle Indonesia, PT Yupi Indo Jelly Gum, PT Torabika, PT URC Indonesia, PT Unican Surya Agung, PT Internusa Food, PT Inkenas Agung dan sebagainya. Peningkatan konsumsi gula yang semakin meningkat dan perkembangan industri makanan dan minuman yang menggunakan gula, akan meningkatkan kebutuhan gula di dalam negeri. PT Raya Sugarindo Inti Tasikmalaya sebagai salah satu industri yang bergerak di bidang gula dituntut untuk dapat memenuhi kebutuhan konsumsi gula di dalam negeri, sehingga dapat membantu pemerintah dalam mewujudkan swasembada gula nasional.

Pada beberapa tahun terakhir, perusahaan belum mampu mencapai target produksi sesuai yang telah direncanakan sebelumnya. Hal ini terlihat dari perbandingan laporan realisasi dan anggaran hasil produksi. Untuk lebih jelasnya dapat dilihat pada tabel 1. sebagai berikut:

\section{Tabel 1}

Realisasi dan Anggaran Hasil Produksi

PT Raya Sugarindo Inti Tasikmalaya 2006-2015

\begin{tabular}{|r|c|c|}
\hline \multirow{2}{*}{ Tahun } & \multicolumn{2}{|c|}{ Produksi (dalam rupiah) } \\
\cline { 2 - 3 } & Realisasi & Anggaran \\
\hline 2006 & $29,312,514,075$ & $29,983,252,272$ \\
\hline 2007 & $34,804,526,044$ & $34,471,498,351$ \\
\hline 2008 & $38,822,589,243$ & $41,367,674,829$ \\
\hline 2009 & $38,007,507,819$ & $44,508,075,883$ \\
\hline 2010 & $47,921,303,068$ & $54,318,060,338$ \\
\hline 2011 & $52,158,032,631$ & $52,500,475,950$ \\
\hline 2012 & $58,400,508,501$ & $58,500,475,950$ \\
\hline 2013 & $68,628,805,642$ & $68,975,485,766$ \\
\hline 2014 & $75,298,230,915$ & $75,687,590,742$ \\
\hline 2015 & $85,839,983,243$ & $85,975,608,317$ \\
\hline Jumlah & $529,194,001,181$ & $546,288,198,398$ \\
\hline Selisih & $\mathbf{1 7 , 0 9 4 , 1 9 7 , 2 1 8}$ & \\
\hline
\end{tabular}

Sumber : Laporan Realisasi dan Anggaran Produksi dan Penjualan PT Raya Sugarindo Inti Tasikmalaya tahun 2006-2015

Dari tabel 1 terlihat bahwa perusahaan belum mampu mencapai target produksi sesuai dengan yang direncanakan. Menurut manajemen perusahaan salah satu hal yang diduga menjadi penyebab tidak tercapainya produksi adalah manajemen mesin-mesin yang kurang dikelola dengan baik, padahal mesin dan sarana produksi lainnya merupakan sumber vital dari kegiatan proses produksi. Tujuan fungsi produksi adalah untuk mengolah sumber daya yang dimiliki perusahaan secara efisien dan efektif sehingga dapat merealisasikan target produksi yang direncanakan. Hasil produksi yang dihasilkan oleh suatu perusahaan akan mencerminkan tingkat produktivitasnya.

Produktivitas itu sendiri adalah mengenai besaran output/keluaran dengan input/masukan. Menurut Kendrick (Griffin, 2002:213) "Produktivitas adalah ukuran 
efisiensi ekonomis yang mengikhtisarkan nilai dari output relatif terhadap nilai dari input yang dipakai untuk menciptakannya". Menurut Mulyadi (2001:466) "Produktivitas berhubungan dengan produksi keluaran secara efisien dan terutama ditujukan kepada hubungan antara keluaran dan masukan yang digunakan untuk menghasilkan keluaran tersebut". Biasanya suatu kombinasi atau campuran masukan dapat digunakan untuk menghasilkan suatu tingkat keluaran tertentu.

Dalam produktivitas, output adalah sejumlah barang dan jasa yang dihasilkan dari proses produksi, sedangkan input adalah faktor-faktor produksi. Menurut Suprihanto (Haryani, 2002:97) "sumber-sumber ekonomi atau sering disebut dengan faktor-faktor produksi mencakup tanah, modal, teknologi, tenaga kerja dan bahan baku".

Produktivitas perusahaan merupakan kemampuan untuk menghasilkan barang dan jasa dengan sumber daya atau faktor-faktor produksi yang dimiliki. Produktivitas perusahaan merupakan faktor penentu level profitabilitas yang utama dan selanjutnya kemampuan untuk bertahan hidup. Untuk meningkatkan produktivitas produksi diperlukan peralatan produksi dengan kondisi fisik yang baik. Sarana produksi dapat tetap beroperasi dengan baik jika perusahaan melakukan pemeliharaan terhadap peralatan produksi tersebut. Seperti yang dikemukakan Handoko (2000:157) bahwa terdapat dua fungsi pelayanan penting kegiatan-kegiatan produksi yaitu pemeliharaan (maintenance) dan penanganan bahan (material handling). Pemeliharaan yang baik menjamin bahwa fasilitas-fasilitas produktif akan beroperasi secara efektif. Hal ini dihasilkan dari suatu kombinasi pemeliharaan preventif yang mengantisipasi daya pakai mesin-mesin dan perbaikan kerusakan, bila terjadi, secepat mungkin sehingga biaya sistem mesin tidak produktif dan tenaga kerja menganggur dapat diminimumkan.

Dengan demikian, perusahaan harus mengeluarkan biaya untuk dapat menjaga peralatan dengan kondisi baik. Dalam hal ini, biaya yang dikeluarkan oleh perusahaan adalah biaya pemeliharaan. Maka, untuk meningkatkan produktivitas produksi, salah satunya bisa dilakukan dengan cara menggunakan biaya pemeliharaan secara efisien. Biaya pemeliharaan sebagai salah satu pembentuk biaya produksi, biaya produksi yang lebih rendah akan mengakibatkan produktivitas lebih tinggi. Efisiensi biaya produksi yang dilakukan dapat disebabkan oleh salah satunya adalah kegiatan pemeliharaan preventif terhadap setiap fasilitas produksi. Artinya, perusahaan dapat mengendalikan biaya produksi salah satunya dengan melakukan penghematan pada biaya pemeliharaan melalui pemeliharaan preventif.

\section{Landasan Teori}

Ravianto (2007:12) mengemukakan pengertian produktivitas adalah "Ukuran efisiensi dengan mana modal, material, peralatan atau teknologi, manajemen sumber daya manusia, informasi dan waktu yang digunakan untuk menghasilkan barang dan jasa". Sedangkan menurut Kendrick (Griffin, 2002:213) "Produktivitas adalah ukuran efisiensi ekonomis yang mengikhtisarkan nilai dari output relatif terhadap nilai dari input yang dipakai untuk menciptakannya". Sejalan dengan yang dikemukakan Mulyadi (2001:466) "Produktivitas berhubungan dengan produksi keluaran secara efisien dan terutama ditujukan kepada hubungan antara keluaran dan masukan yang digunakan untuk menghasilkan keluaran tersebut". Biasanya suatu kombinasi atau campuran masukan dapat digunakan untuk menghasilkan suatu tingkat keluaran tertentu.

Apabila ukuran keberhasilan produksi hanya dipandang dari sisi output, maka produktivitas dipandang dari dua sisi sekaligus, yaitu sisi input dan sisi output. Dengan demikian produktivitas berkaitan dengan efisiensi penggunaan input dalam memproduksi output (barang atau jasa).

Mali (Gasperz, 2000:18) menyatakan bahwa produktivitas tidak sama dengan produksi, tetapi produksi, performansi kualitas, hasil-hasil, merupakan komponen 
dari usaha produktivitas. Dengan demikian, produktivitas merupakan suatu kombinasi dari efektivitas dan efisiensi, sehingga produktivitas dapat diukur berdasarkan pengukuran berikut :

$$
\begin{aligned}
& \text { Produktivitas }=\frac{\text { output yang dihasilkan }}{\text { input yang dipergunakan }} \\
& =\frac{\text { pencapaian tujuan }}{\text { penggunaan sumber }- \text { sumber daya }} \\
& =\frac{\text { efektivitas pelaksanaan tugas }}{\text { efisiensi penggunaan sumber }- \text { sumber daya }}
\end{aligned}
$$

(Gasperz, 2000:18)

$\begin{array}{crrr}\text { Secara } & \text { umum formula yang } \\ \text { dipergunakan } & \text { dalam } & \text { pengukuran }\end{array}$ produktivitas sesuai dengan formula menurut Mulyadi (2001:467) adalah sebagai berikut:

$$
\text { Produktivitas }=\frac{\text { keluaran }}{\text { masukan }}
$$

Berikut ini beberapa formula produktivitas menurut Muchdarsyah (2008:23)

$$
\begin{aligned}
\text { Produktivitas Parsial } & =\frac{\text { output parsial }}{\text { input total }} \\
\text { Produktivitas Total } & =\frac{\text { output total }}{\text { input total }}
\end{aligned}
$$

Pengukuran produktivitas berkenaan dengan penilaian kuantitatif terhadap perubahan produktivitas. Tujuannya adalah untuk menilai apakah efisiensi produksi telah meningkat atau menurun. Pengukuran produktivitas dapat dikembangkan untuk setiap input secara terpisah atau untuk semua input bersama-sama.

Pengukuran produktivitas produksi yaitu dengan membandingkan antara output yang di hasilkan dan biaya input sumber daya input yang diperlukan untuk memproduksi output. Formula pengukuran produktivitasnya adalah sebagai berikut:

$$
\text { Produktivitas }=\frac{\text { output yang dihasilkan }}{\text { input yang dipergunakan }}
$$

Gasperz, 2000:34)

Produktivitas produksi merupakan ukuran produktivitas keuangan (financial productivity). Satuan moneter mencerminkan faktor umum yang memungkinkan pengukuran produktivitas bersama berbagai sumber daya, seperti bahan baku, tenaga kerja dan faktor produksi lainnya.

\section{Metode Penelitian}

Metode yang digunakan dalam penelitian ini adalah metode deskriptif. Menurut Sugiyono (2011:35) "Rumusan masalah deskriptif adalah suatu rumusan masalah yang berkenaan dengan pertanyaan terhadap variabel mandiri, baik hanya pada satu variabel atau lebih (variabel yang berdiri sendiri)". Menurut Arikunto (2006:8) "Penelitian yang bertujuan untuk mengecek hasil penelitian lain inilah yang diberi nama verifikatif". Penelitian verifikatif dimaksudkan untuk menguji kebenaran suatu hipotesis yang dilakukan melalui pengumpulan data di lapangan. Melalui metode penelitian deskriptif dapat diperoleh deskripsi mengenai bagaimana efisiensi biaya pemeliharaan mesin dan produktivitas produksi pada PT Raya Sugarindo Inti Tasikmalaya pada tahun 2001 sampai 2010. Penelitian verifikatif bertujuan untuk menguji apakah efisiensi biaya pemeliharaan mesin berpengaruh terhadap produktivitas produksi pada PT Raya Sugarindo Inti Tasikmalaya.

Sumber data yang digunakan dalam penelitian ini adalah berupa dokumen dari laporan realisasi dan anggaran hasil produksi dan penjualan PT Raya Sugarindo Inti Tasikmalaya dari periode 2006 sampai 2015 yang disajikan dalam bentuk per tahun sehingga berjumlah 10 tahun.

Teknik pengumpulan data yang digunakan dalam penelitian ini adalah telaah dokumen. Telaah dokumen bertujuan untuk mengetahui data dari subjek penelitian. Telaah ini digunakan untuk mencari atau memperoleh data berupa catatan, laporan serta dokumen yang berkaitan dengan variabel yang diteliti. Dokumen tersebut 
berupa laporan realisasi dan anggaran hasil produksi dan penjualan PT Raya Sugarindo Inti Tasikmalaya.

Adapun langkah-langkah atau teknik pengolahan data yang digunakan dalam penelitian ini adalah sebagai berikut :

1. Menghitung efisiensi biaya pemeliharaan mesin

2. Menghitung produktivitas produksi

Untuk mengetahui seberapa besar pengaruh efisiensi biaya pemeliharaan mesin terhadap produktivitas produksi, maka data yang diperoleh dianalisis dengan menggunakan uji statistik dengan menggunakan tahapan sebagai berikut :

1. Menetukan nilai masing-masing variabel

2. Uji linieritas regresi

Uji linieritas dimaksudkan untuk mengetahui kemungkinan adanya hubungan linier antar variabel independen $(X)$ dengan variabel dependen (Y). Pengujian ini dilakukan dengan menggunakan SPSS versi 20.

3. Analisis Regresi Sederhana

4. Kriteria Penerimaan dan Penolakan Hipotesis

Dasar pengambilan keputusan untuk menguji hipotesis yang diajukan dapat dirumuskan sebagai berikut:

a. Apabila nilai $b$ (koefisien regresi efisiensi biaya pemeliharaan mesin) bernilai positif maka hipotesis yang diajukan ditolak. Koefisien arah regresi positif ditunjukan dalam persamaan $\hat{Y}=a+b X$.

b. Apabila nilai $b$ (koefisien regresi efisiensi biaya pemeliharaan mesin) bernilai negatif maka hipotesis yang diajukan diterima. Koefisien arah regresi negatif ditunjukan dalam persamaan $\hat{\mathrm{Y}}=a-b X$.

\section{Hasil dan Pembahasan}

Berdasarkan data yang diperoleh, dapat diketahui bahwa PT Raya Sugarindo Inti Tasikmalaya telah mengeluarkan biaya pemeliharaan mesin dengan kenaikan dan penurunan yang beragam setiap tahunnya.
Pencapaian efisiensi biaya pemeliharaan mesin berada di atas rata-rata setiap tahunnya yaitu sebesar $11,40 \%$, sehingga dapat dikategorikan tinggi. Efisiensi biaya pemeliharaan mesin lebih tinggi dicapai jika biaya pemeliharaan yang dikeluarkan relatif lebih rendah, sedangkan efisiensi biaya pemeliharaan mesin rendah dicapai jika biaya pemeliharaan yang dikeluarkan relatif lebih besar.

Perubahan efisiensi biaya pemeliharaan mesin diakibatkan adanya perubahan jumlah biaya pemeliharaan yang dikeluarkan perusahaan setiap tahunnya dengan kebijakan pemeliharaan yang dilakukan tergantung pada kondisi mesin dan sarana produksi. Biaya pemeliharaan rutin merupakan jumlah biaya minimum yang pasti dikeluarkan perusahaan, sedangkan unsur biaya lainnya dipengaruhi oleh kondisi mesin dan sarana produksi, perubahan volume proses produksi serta alternatif kebijakan pemeliharaan.

Efisiensi biaya pemeliharaan mesin dilakukan untuk menjaga kondisi mesin dan sarana produksi tetap berada dalam kondisi yang baik sehingga dapat beroperasi secara optimal dan menghindari kemungkinankemungkinan terjadinya kerusakan yang dapat menghambat proses produksi.

Produktivitas produksi yang dicapai PT Raya Sugarindo Inti mengalami suatu kenaikan dan penurunan setiap tahunnya dengan rata-rata setiap tahunnya mencapai angka 1,16. Kenaikan produktivitas produksi bisa disebabkan karena perusahaan mampu menghasilkan jumlah produk yang besar dengan mengefisiensikan biaya yang dikeluarkan dalam proses produksi, dan penurunan produktivitas bisa disebabkan karena perusahaan tidak bisa menghasilkan jumlah produk yang lebih besar sedangkan biaya yang dikeluarkan dalam proses produksi besar.

Berdasarkan kebijakan perusahaan
bahwa perusahaan menargetkan
produktivitas produksi yang dicapai harus
mencapai angka 2,0 maka dengan demikian
perusahaan belum bisa mencapai target


produktivitas produksi yang telah ditetapkan, sehingga produktivitas produksi yang dicapai oleh perusahaan dapat dikategorikan rendah.

Prinsip ekonomis secara sederhana berarti menghindarkan segala bentuk pemborosan atau dengan kata lain adalah penghematan. Efisiensi biaya pemeliharaan dipengaruhi oleh penjadwalan produksi, perawatan mesin, faktor kualitas, waktu istirahat operator, kerusakan mesin, adanya produk cacat, dan kekurangan biaya bahan baku. Masalah efisiensi dalam manajemen pemeliharaan lebih ditekankan pada aspek ekonomis dengan memperhatikan besarnya biaya yang terjadi, dan alternatif tindakan yang dipilih untuk dilaksanakan sehingga perusahaan dapat memperoleh keuntungan. Artinya perusahaan berusaha melakukan pengendalian pada kegiatan pemeliharaan sehingga efisiensi biaya pemeliharaan mesin tercapai, namun mesin dan sarana produksi tidak dapat berjalan secara optimum. Efisien berbeda halnya dengan optimal, efisiensi biaya yang dilakukan perusahaan bisa mengakibatkan pemeliharaan-pemeliharaan yang seharusnya dilakukan dihindari sehingga perusahaan tidak perlu mengeluarkan biaya dengan jumlah relatif lebih besar yang mengakibatkan mesin dan sarana produksi tidak dapat bekerja secara optimal.

Hasil perhitungan statistik pada penelitian ini menunjukan bahwa efisiensi biaya pemeliharaan berpengaruh negatif terhadap produktivitas produksi. Hal ini terlihat pada persamaan regresi sederhana yang diperoleh $\hat{\mathrm{Y}}=1,615-0,029 \mathrm{X}$, dapat diketahui nilai konstanta sebesar 1,615 menunjukan bahwa jika tidak terjadi perubahan pada biaya pemeliharaan mesin, maka produktivitas produksi pada PT Raya Sugarindo Inti Tasikmalaya adalah sebesar 1,615. Sedangkan tanda negatif (-) pada persamaan regresi tersebut menunjukan adanya koefisien arah regresi yang negatif. Hal ini berarti bahwa setiap terjadi kenaikan pada efisiensi biaya pemeliharaan mesin akan menurunkan produktivitas produksi ataupun sebaliknya. Koefisien regresi sebesar -0,029 menunjukan bahwa kenaikan efisiensi biaya pemeliharaan mesin sebesar Rp 1 akan menurunkan produktivitas produksi sebesar $\mathrm{Rp}$ 0,029.

Berdasarkan data-data yang telah dianalisis, maka produktivitas produksi PT Raya Sugarindo Inti Tasikmalaya mengalami peningkatan disaat jumlah output (hasil produksi) melebihi input (biaya produksi) yang digunakan atau dengan kata lain bahwa perusahaan mampu menyeimbangakan antara penggunaan sumber daya yang digunakan (input) dalam usaha pencapaian hasil (output). Produktivitas produksi dapat dikatakan belum maksimal dan belum mencapai target yang sudah ditetapkan sebelumnya sehingga dapat dikategorikan rendah. Hal ini dikarenakan biaya pemeliharaan mesin yang dikeluarkan relatif rendah mengakibatkan adanya pengurangan kegiatan pemeliharaan sehingga efisiensi biaya pemeliharaan mesin yang dicapai tinggi. Efisiensi biaya pemeliharaan mesin selain dapat mengendalikan biaya juga dapat digunakan untuk menekan kegiatan pemeliharaan.

Berdasarkan hasil penelitian yang dilakukan di PT Raya Sugarindo Inti Tasikmalaya, dan sejalan dengan pendapat yang dikemukakan oleh Heizer dan Render (2001:485), "Efisiensi biaya produksi yang lebih rendah akan mengakibatkan produktivitas yang lebih tinggi. Hal ini disebabkan bahwa produktivitas dapat diartikan sebagai output dibagi dengan input". Dimana biaya pemeliharaan merupakan komponen dari biaya produksi sehingga efisiensi biaya pemeliharaan mesin yang dilakukan dapat mempengaruhi efisiensi biaya produksi. Penelitian yang penulis lakukan ini didukung oleh hasil penelitian terdahulu yang dilakukan oleh Retnosari Febriyanti (2009), yang berjudul "Pengaruh Biaya Perbaikan dan Pemeliharaan Aktiva Tetap Terhadap Tingkat Produktivitas Pada PT Industri Sandang Nusantara Unit Patal Banjaran". Hasil perhitungan statistik menunjukan persamaan regresi yang diperoleh adalah $\hat{Y}=0,027-0,314 X$. Nilai koefisien arah regresi yang diperoleh adalah negatif, artinya variabel $X$ yaitu biaya 
pemeliharaan memiliki pengaruh negatif atau sifatnya berlawanan arah terhadap produktivitas produksi. Dengan demikian dapat disimpulkan bahwa hipotesis yang diajukan yaitu efisiensi biaya pemeliharaan berpengaruh negatif terhadap produktivitas produksi dalam penelitian ini teruji dan dapat diterima.

\section{Simpulan}

Simpulan dari hasil penelitian yang telah dilakukan yaitu pengaruh efisiensi biaya pemeliharaan mesin terhadap produktivitas produksi pada PT Raya Sugarindo Inti Tasikmalaya tahun 2001 sampai 2010 adalah sebagai berikut:

1. Efisiensi biaya pemeliharaan mesin pada PT Raya Sugarindo Inti Tasikmalaya selama periode 2001 sampai dengan 2010 dapat dikendalikan dengan baik, hal ini ditunjukan dengan pencapaian efisiensi biaya pemeliharaan mesin pada kategori tinggi.

2. Produktivitas produksi pada PT Raya Sugarindo Inti Tasikmalaya selama periode 2001 sampai dengan 2010 belum memenuhi target kebijakan perusahaan, hal ini ditunjukan dengan pencapaian produktivitas produksi yang dapat dikategorikan rendah.

3. Berdasarkan perhitungan statistik diperoleh persamaan regresi efisiensi biaya pemeliharaan mesin dengan produktivitas produksi pada PT Raya Sugarindo Inti Tasikmalaya yang menunjukan koefisien arah regresi negatif. Dengan demikian hipotesis yang diajukan diterima.

\section{Daftar Pustaka}

Ahyari, A. (2002). Manajemen Produksi Pengendalian Produksi. Yogyakarta: BPFE
Anthony, R N dan Govindaraja, V. (2002). Sistem Pengendalian Manajemen. Jakarta:Salemba Empat

Arikunto, S. (2006). Prosedur Penelitian Suatu Pendekatan Praktik. Jakarta: Rineka Cipta

Assauri, S. (2008). Manajemen Operasi dan Produksi. Jakarta: Lembaga Penerbit FEUI

Gasper, V. (2000). Manajemen Produksi Total-Strategi Peningkatan Produktivitas Bisnis Global. Jakarta: Gramedia Pustaka

Halim, A. (2000). Sistem Pengendalian Manajemen. Yogyakarta: Unit Penerbit dan Percetakan Akademi Manajemen Perusahaan YKPN.

Handoko, T. Hani. (2000). Dasar-Dasar Manajemen Produksi dan Operasi. Yogyakarta: BPFE

Haryani, S. (2002). Hubungan Industrial di Indonesia. Yogyakarta: AMP YKIPN

Heizer J dan Render B. (2001). PrinsipPrinsip Manajemen Operrasi. Jakarta: Salemba Empat

Herjanto, E. (2008). Manajemen Produksi dan Operasi. Jakarta: PT Gramedia Widiasarana Indonesia

Muchdarsyah, S. (2008). Produktivitas Apa dan Bagaimana. Jakarta: PT Bumi Aksara

Mulyadi. (2001). Akuntansi Manajemen. Jakarta: Salemba Empat

\section{Yogyakarta: YKPN}

Mulyadi, A.(2002) Akuntansi Manajemen. Bandung: BP Prodi Pendidikan Akuntansi UPI

Mulyono, M. (2008). Penerapan Produktivitas dalam Organisasi. Jakarta: Bumi Aksara

Ravianto J. (2007. Produktivitas dan Teknologi. Jakarta: PT Indeks Kelompok Informasi Usaha 
Sadeli, M L dan Siswanto, B. (2010). Akuntansi Manajemen. Jakarta: Bumi Aksara

Sawit, M H. (2001). "Kebijakan Swasembada Gula: Apanya Yang Kurang?". Analisis Kebijakan Pertanian. 8, 285:302. [Online]. Tersedia :http://www.google.co.id/url?sa=t\&rct= $\mathrm{i} \& \mathrm{q}=\& \mathrm{esrc}=\mathrm{s} \&$ source $=$ web \&cd $=2 \& \mathrm{sqi}$ $=2 \&$ ved $=0$ CCsQFiAB\&url=http $\% 3 \mathrm{~A} \% 2$ F\%2Fpse.litbang.deptan.go.id\%2Find \%2Fpdffiles\%2FART84a.pdf\&ei=Rmu BT9bxCoTkrAfLIt2GBg\&usg=AFQjCN HCg3TQC4fIFHETqewBKdPNaxXKA w\&sig2=VIUtV1-76QfeyiVAEsdhQw
Sembiring, R K. (2003). Analisis Regresi. Bandung: ITB

Simamora, H. (2001). Akuntansi Manjemen. Jakarta: Salemba Empat.

Sudjana. (2003). Teknik Analisis dan Regresi. Bandung: Tarsito.

Sugiyono. (2011). Metode Penelitian Kuantitatif Kualitatif dan R\&D. Bandung: Alfabeta

Supriyono. (2000). Akuntansi Manajemen 2. Yogyakarta : STIE YKPN 